\title{
Alcoholic chronic pancreatitis: A quality of life study
}

\section{Pancreatite crônica alcoólica: \\ um estudo de qualidade de vida}

\section{A B S T R A C T}

\section{Objective}

To compare the quality of life between patients with alcoholic chronic pancreatitis and controls, and between diabetic and non-diabetic patients, correlating clinical, sociodemographic, and nutritional factors with their quality of life scores.

\section{Methods}

Forty-three outpatients of the pancreas and biliary tract clinic diagnosed with alcoholic chronic pancreatitis were assessed. Quality of life was measured by the Brazilian version of the Short Form-36. The control group consisted of 43 healthy companions. Nutritional status was classified according to body mass index and triceps, biceps, suprailiac, and subscapular skinfold thicknesses, using the appropriate methods. The percentage of body fat was given by adding the four skinfold thicknesses and by bioelectrical impedance analysis. The statistical tests included the Chi-square, Mann-Whitney, and Spearman's correlation tests, with the significance level set at $p<0.05$.

\section{Results}

The sociodemographic variables of the case and control groups did not differ. Quality of life was lower in alcoholic chronic pancreatitis patients than in controls. The only quality of life domain that differed between diabetics and non-diabetics was functional capacity, lower in diabetics $(p=0.022)$. Smoking duration, alcohol intake in grams, and time since pancreatic surgery correlated negatively with the quality of life of alcoholic chronic pancreatitis patients. Old age, skinfold thicknesses, and percentage of body fat correlated positively with quality of life.

\footnotetext{
1 Universidade Federal de São Paulo, Escola Paulista de Medicina, Departamento de Medicina. R. Pedro de Toledo, 715 , $2^{\circ}$ Andar, Vila Clementino, 5576-4050, São Paulo, SP, Brasil. Correspondência para/Correspondence to: ED LIBERA JÚNIOR. E-mail: <ermelindo.libera@grupofleury.com.br>.

Article based on master's thesis of SC BENINCÁ, intitled "Avaliação da qualidade de vida e do estado nutricional em pacientes com pancreatite crônica alcoólica”. Universidade Federal de São Paulo; 2013.
} 


\section{Conclusion}

Quality of life is low in alcoholic chronic pancreatitis patients because of the negative influence of certain factors, such as smoking duration, amount of alcohol consumed, and time since pancreatic surgery.

Keywords: Diabetes Mellitus. Pancreatitis, alcoholic. Pancreatitis, chronic. Quality of life.

\section{R E S U M O}

\section{Objetivo}

Avaliar a qualidade de vida dos pacientes com pancreatite crônica alcoólica, comparando-os aos participantes de um grupo-controle e entre pacientes com e sem diabetes.

\section{Métodos}

Avaliaram-se 43 pacientes do ambulatório de pâncreas e vias biliares diagnosticados com pancreatite crônica alcoólica. A qualidade de vida foi verificada por meio do Short Form-36, versão brasileira. O grupo-controle para a qualidade de vida foi composto por 43 acompanhantes sem doenças conhecidas. Para avaliação do estado nutricional, foi calculado o índice de massa corporal e dobras cutâneas do tríceps, bíceps, suprailíaca e subescapular, de acordo com a metodologia adequada. Para obtenção da porcentagem de gordura corporal, utilizou-se o somatório das quatro dobras e a medida obtida por meio da bioimpedância. Para análise estatística, foi utilizado teste de Qui-quadrado, Mann-Whitney e correlação de Spearmam, com p<0,05.

\section{Resultados}

Não houve diferença entre o grupo-caso e o grupo-controle para as variáveis sociodemográficas. A qualidade de vida dos pacientes com pancreatite crônica alcoólica mostrou-se diminuída quando comparada aos membros do grupo-controle. Ao serem comparados os domínios de qualidade de vida dos pacientes com e sem diabetes, somente o quesito capacidade funcional apresentou diferença: menor para o grupo com diabetes $(p=0,022)$. A correlação mostrou que o tempo de tabagismo, a quantidade de etanol em gramas e o tempo de cirurgia pancreática incidiram negativamente na qualidade de vida do grupo com pancreatite crônica alcoólica. Idade avançada, pregas cutâneas e porcentagem de gordura corporal se correlacionaram positivamente com qualidade de vida.

\section{Conclusão}

A qualidade de vida está diminuída no grupo com pancreatite crônica alcoólica devido à influência negativa de fatores como tempo de tabagismo, quantidade de etanol e tempo de cirurgia pancreática.

Palavras-chave: Diabetes Mellitus. Pancreatite alcoólica. Pancreatite crônica. Qualidade de vida.

\section{INTRODUCTION}

The main characteristics of chronic pancreatitis are presence of abdominal pain and clinical manifestations secondary to endocrine and exocrine pancreatic insufficiency'. Chronic pancreatitis is characterized by chronic inflammation with anatomical lesions and substitution of the normal parenchyma by fibrous tissue, and later, pancreatic calcification ${ }^{2}$. The disease is caused mainly by chronic alcohol abuse ${ }^{3}$. In our practice alcoholism is responsible for most cases, affecting mainly males ${ }^{4,5}$.

Quality of life can be measured by specific questionnaires with closed questions. The Short
Form-36 (SF-36), an instrument that measures quality of life, was developed in the late 1980s in the United States of America. It has been used in diverse situations, presenting good sensitivity ${ }^{6,7}$. This instrument has been translated and validated in Brazil to measure the quality of life of patients with rheumatoid arthritis and proved to be appropriate for the local conditions ${ }^{8}$. Its greater scope allows its use in different clinical situations and on healthy individuals 8,9 .

Quality of life is low in approximately 85\% of the patients with chronic pancreatitis, especially the younger patients, with social consequences ${ }^{10-12}$. Chronic pain is the main deteriorator of the quality of life of these patients, more so than other 
associated diseases ${ }^{13}$. Gastrointestinal, metabolic, and nutritional (low body mass index) factors also deteriorate quality of life. Diabetes also hurts quality of life, especially the body and mental health domains ${ }^{10,11,14}$.

This study aimed to compare quality of life between patients with alcoholic chronic pancreatitis and healthy controls, and between diabetic and non-diabetic alcoholic chronic pancreatitis patients; and then to correlate clinical, sociodemographic, and nutritional factors with quality of life.

\section{METHODS}

This prospective, cross-sectional study was conducted from January 2011 to May 2012 after approval of the Research Ethics Committee of the Universidade Federal de São Paulo under Protocol $n^{\circ}$ 1944/10. Forty-three outpatients diagnosed with alcoholic chronic pancreatitis were interviewed. The control group consisted of 43 healthy companions who only provided sociodemographic data and answered the quality of life questionnaire (SF-36). This group was selected randomly among outpatients' companions. All individuals in both groups were males. The study participants were interviewed and answered a questionnaire about their diagnoses and associated clinical conditions. The alcohol intake reported by each patient was converted to grams of ethanol/day ${ }^{15}$.

Quality of life was measured by the Brazilian version of the SF-36 questionnare ${ }^{8}$. The questionnaire consists of 11 questions and 36 items in eight domains, namely functional capacity, role physical, bodily pain, general health, vitality, social functioning, role emotional, and mental health. The answers were tabulated and weighted according to specific formulas and values for each answer or domain, with scores that varied from 0 (worst) to 100 (best), according to the criteria proposed by Ware et al. ${ }^{6}$.

Nutritional status was classified according to the Body Mass Index (BMI), given by dividing weight $(\mathrm{kg})$ by height squared $\left(\mathrm{m}^{2}\right)$. Nutritional status was classified according to the cut-off points for adults and older adults proposed by the World Health Organization ${ }^{16}$ and Organização Pan-Americana de Saúde ${ }^{17}$, respectively. The triceps, biceps, suprailiac, and subscapular skinfold thicknesses were measured in $\mathrm{mm}$ by the precision caliper Lange ${ }^{\circledast}$ (Creative Health Products, Ann Arbor, Michigan, United States). Arm circumference and skinfold thicknesses were measured as recommended by Heyward \& Stolarczyck ${ }^{18}$. The percentage of body fat was given by adding the four skinfold thicknesses (triceps skinfold thickness, biceps skinfold thickness, suprailiac skinfold thickness, and subscapular skinfold thickness) as proposed by Durnin \& Womersley ${ }^{19}$, and by Bioelectrical Impedance Analysis (BIA), using the device Biodynamics ${ }^{\circledR}$ (Biodynamics Corporation, Shoreline, Washington, United States) and the patient's weight and height measured earlier. The percentage-of-body-fat values were compared with the reference values established by Lohman ${ }^{20}$ for males.

The quantitative variables were expressed as mean and standard deviation, and the categorical (qualitative) variables were expressed as absolute frequency and percentage using descriptive statistics. The Kolmogorov-Smirnov test investigated whether the variables had normal distribution. The Chi-square test compared the groups. The Fisher's test was used on frequencies below five. Correlations between nonparametric variables were determined by Spearman's correlation. The Mann-Whitney test compared the nonparametric variables and the SF-36 domain scores with the categorical variables. The significance level was set at $5 \%$ $(p<0.05)$. All analyses were performed by the Statistical Package for the Social Science (SPSS Inc., Chicago, Illinois, United States) for Windows, version 18.0 and Microsoft ${ }^{\circledR}$ Excel 2007 (Microsoft Corporation, Redmond, Washington, United States). 


\section{RE S U L T S}

Forty-three individuals were included in the case group (patients) and another 43 in the control group (companions). All participants were male, and the mean ages of both groups were similar. Education level categories between the groups were also compared. Education level, number of household members, mean monthly income, and per capita monthly income did not differ between the groups (Table 1).

Table 2 shows patients' clinical characteristics, smoking status, alcohol intake data, and nutritional

Table 1. General characteristics of the study groups. São Paulo (SP), Brazil, 2012-2013.

\begin{tabular}{|c|c|c|c|c|c|c|c|c|c|}
\hline \multirow{2}{*}{ Characteristics } & \multicolumn{4}{|c|}{ Case group } & \multicolumn{4}{|c|}{ Cotrol group } & \multirow{2}{*}{$p$-value } \\
\hline & M & SD & AV & $\%$ & M & SD & AV & $\%$ & \\
\hline \multicolumn{10}{|l|}{ Gender } \\
\hline Male & 43.0 & 100.0 & & & 43.0 & 100.0 & & & $\mathrm{NS}^{*}$ \\
\hline Age & 52.9 & 9.40 & & & 48.9 & 10.6 & & & $\mathrm{NS}^{*}$ \\
\hline \multicolumn{10}{|l|}{ Education level } \\
\hline Elementary school & & & 31.0 & 72.1 & & & 22.0 & 51.2 & \\
\hline High school & & & 8.0 & 18.6 & & & 15.0 & 34.9 & \\
\hline Higher education & & & 4.0 & 9.3 & & & 6.0 & 14.0 & $N S^{* *}$ \\
\hline № people in household & 3.2 & 1.80 & & & 3.5 & 1.5 & & & $\mathrm{NS}^{*}$ \\
\hline Monthly income ( $R \$)$ & 2022.4 & 1503.0 & & & 2265.6 & 1741.9 & & & $\mathrm{NS}^{*}$ \\
\hline Monthly income per capita ( $R \$)$ & 697.8 & 473.0 & & & 751.4 & 760.8 & & & $\mathrm{NS}^{*}$ \\
\hline
\end{tabular}

Note: "Mann-Whitney test; ${ }^{* *}$ Chi-square test.

NS: Not Significant; M: Mean; SD: Standard Desviation; AV: Absolut Values.

Table 2. Clinical and nutritional characterization of patients with alcoholic chronic pancreatitis. São Paulo (SP), Brazil, $2012-2013$.

\begin{tabular}{|c|c|c|c|c|c|c|}
\hline \multirow{2}{*}{ Characteristcs } & \multirow{2}{*}{ M } & \multirow{2}{*}{ SD } & \multicolumn{2}{|c|}{ Yes } & \multicolumn{2}{|c|}{ No } \\
\hline & & & $n$ & $\%$ & $\mathrm{n}$ & $\%$ \\
\hline Alcoholic chronic pancreatitis duration (years) & 8.20 & 7.55 & & & & \\
\hline Presence of diabetes Mellitus/n (\%) & & & 22 & 51.2 & 21 & 48.8 \\
\hline Diabetes Mellitus duration (years) & 4.27 & 5.99 & & & & \\
\hline Associated diseases/n (\%) & & & 37 & 86.0 & 6 & 14.0 \\
\hline Use of enzymes/n (\%) & & & 34 & 79.1 & 9 & 20.9 \\
\hline Enzyme use duration (m) & 43.98 & 47.46 & & & & \\
\hline Pain/n (\%) & & & 11 & 25.6 & 32 & 74.4 \\
\hline Pancreatic surgery/n (\%) & & & 12 & 27.9 & 31 & 72.1 \\
\hline Time since surgery (years) & 3.56 & 7.53 & & & & \\
\hline Smoker/n (\%) & & & 27 & 62.8 & 16 & 37.2 \\
\hline Quit smoking (years ago) & 9.00 & 20.93 & & & & \\
\hline Smoking duration (years) & 27.72 & 14.59 & & & & \\
\hline Alcohol use/n (\%) & & & 10 & 23.3 & 33 & 76.7 \\
\hline Alcoholism duration (years) & 23.23 & 10.87 & & & & \\
\hline Grams of ethanol/day & 247.32 & 291.54 & & & & \\
\hline Body mass index & 22.38 & 3.89 & & & & \\
\hline Triceps skinfold thickness & 9.20 & 5.35 & & & & \\
\hline Biceps skinfold thickness & 4.74 & 2.88 & & & & \\
\hline Subscapular skinfold thickness & 12.17 & 6.86 & & & & \\
\hline Suprailiac skinfold thickness & 12.10 & 7.95 & & & & \\
\hline$\%$ of body fat $\sum 4$ skinfold thickness & 19.80 & 7.07 & & & & \\
\hline$\%$ of body fat BIA & 21.77 & 7.22 & & & & \\
\hline
\end{tabular}

Note: M: Mean; SD: Standard Deviation; BIA: Bioelectrical Impedance Analysis 
assessment data. The mean alcoholic chronic pancreatitis duration was $8.20( \pm 7.55)$ years, and $22(51.2 \%)$ patients were also diabetic. Thirtyfour $(79.1 \%)$ patients used enzymes. Only 11 (25.6\%) patients still experienced pain. Twelve (27.9\%) patients had had pancreatic surgery. Twenty-seven (62.8\%) patients were smokers and $7(16.27 \%)$ had never smoked. Ten $(23.3 \%)$ patients were still consuming alcohol. Mean alcoholism duration was $23.23( \pm 10.87)$ years and mean intake, $247.32( \pm 291.54)$ grams of ethanol per day. Mean BMI was $22.38( \pm 3.89) \mathrm{kg} / \mathrm{m}^{2}$, the percentage of body fat obtained by adding the four skinfold thicknesses was $19.80 \%( \pm 7.07 \%)$, and that determined by BIA was $21.77 \%$ $( \pm 7.22 \%)$.

The case and control groups differed significantly in all quality of life domains (Table
3). Cases had smaller means, that is, patients with alcoholic chronic pancreatitis had low quality of life compared with healthy patients.

Comparison of the eight quality of life (SF-36) domains of diabetic and non-diabetic cases showed that only functional capacity differed ( $p=0.022$ ) (Table 4).

Correlation of sociodemographic, clinical, and nutritional factors with the eight quality of life domains (Table 5) showed that the functional capacity domain was inversely correlated with smoking duration $(p<0.05)$. On the other hand, the functional capacity domain correlated positively with biceps and suprailiac skinfold thicknesses $(p<0.05)$.

The bodily pain domain was inversely correlated with the amount of ethanol consumed

Table 3. Scores for the eight quality of life domains of Short Form-36 for cases and controls. São Paulo (SP), Brazil, 2012-2013.

\begin{tabular}{|c|c|c|c|c|c|}
\hline \multirow{2}{*}{ Domains } & \multicolumn{2}{|c|}{ Case group } & \multicolumn{2}{|c|}{ Control group } & \multirow{2}{*}{$p$-value ${ }^{*}$} \\
\hline & $\mathrm{M}$ & SD & M & SD & \\
\hline Functional capacity & 68.49 & 23.79 & 86.98 & 27.73 & 0.000 \\
\hline Role physical & 50.58 & 40.63 & 81.40 & 33.67 & 0.000 \\
\hline Bodily pain & 52.56 & 25.38 & 76.63 & 21.74 & 0.000 \\
\hline General health & 41.44 & 15.34 & 62.72 & 13.70 & 0.000 \\
\hline Vitality & 54.30 & 15.37 & 70.35 & 12.36 & 0.000 \\
\hline Social functioning & 66.57 & 25.25 & 86.34 & 17.21 & 0.000 \\
\hline Role emotional & 51.16 & 42.63 & 82.17 & 31.99 & 0.000 \\
\hline Mental health & 55.63 & 15.56 & 72.28 & 12.26 & 0.000 \\
\hline
\end{tabular}

Note: *Mann-Whitney test.

M: Mean; SD: Standard Deviation.

Table 4. Scores for the eight quality of life domains of Short Form-36 for diabetics and nondiabetics. São Paulo (SP), Brazil, $2012-2013$.

\begin{tabular}{|c|c|c|c|c|c|}
\hline \multirow{2}{*}{ Domains } & \multicolumn{2}{|c|}{ Diabetics $n=22$} & \multicolumn{2}{|c|}{ Non-diabetics n=21 } & \multirow{2}{*}{$p$-value* } \\
\hline & M & SD & M & SD & \\
\hline Functional capacity & 61.19 & 22.35 & 75.45 & 23.49 & 0.022 \\
\hline Role physical & 42.24 & 42.29 & 55.68 & 39.28 & NS \\
\hline Bodily pain & 52.52 & 22.38 & 52.59 & 28.48 & NS \\
\hline General health & 38.95 & 18.43 & 43.82 & 11.62 & NS \\
\hline Vitality & 54.05 & 18.07 & 54.55 & 12.71 & NS \\
\hline Social functioning & 70.24 & 21.82 & 63.07 & 28.21 & NS \\
\hline Role emotional & 47.62 & 44.18 & 54.54 & 41.84 & NS \\
\hline Mental health & 57.33 & 14.38 & 54.00 & 16.77 & NS \\
\hline
\end{tabular}

Note: *Teste Mann-Whitney.

M: Mean; SD: Standard Deviation; NS: Not Significant. 
Table 5. Correlation between the quality of life domains and sociodemographic, clinical, and nutritional factors. São Paulo (SP), Brazil, 2012-2013.

\begin{tabular}{lcccccccc}
\hline Evaluated factors & $\mathrm{FC}^{*}$ & $\mathrm{RP}^{*}$ & $\mathrm{BP}^{*}$ & $\mathrm{GH}^{*}$ & $\mathrm{~V}^{*}$ & $\mathrm{SF}^{*}$ & $\mathrm{RE}^{*}$ & $\mathrm{MH}^{*}$ \\
\hline Age (y) & 0.447 & 0.304 & 0.360 & 0.771 & 0.203 & 0.561 & 0.325 & $<0.01(+)$ \\
Per capita income & 0.217 & 0.086 & 0.172 & 0.925 & 0.562 & 0.602 & 0.288 & 0.147 \\
Alcoholic chronic pancreatitis duration (y) & 0.512 & 0.198 & 0.312 & 0.511 & 0.473 & 0.084 & 0.461 & 0.711 \\
Diabetes Mellitus duration (y) & 0.065 & 0.752 & 0.569 & 0.469 & 0.637 & 0.610 & 0.591 & 0.753 \\
Enzyme use duration (m) & 0.503 & 0.276 & 0.718 & 0.725 & 0.974 & 0.460 & 0.589 & 0.935 \\
Time since surgery (y) & 0.775 & 0.231 & 0.258 & 0.151 & 0.131 & 0.546 & $<0.05(-)$ & $<0.05(-)$ \\
Smoking duration (y) & $<0.05(-)$ & 0.557 & 0.154 & 0.184 & 0.164 & 0.115 & 0.502 & 0.873 \\
Grams of ethanol/day & 0.690 & 0.258 & $<0.01(-)$ & 0.091 & 0.841 & 0.699 & 0.544 & $<0.05(-)$ \\
Alcoholism duration (y) & 0.546 & 0.595 & 0.484 & 0.117 & 0.356 & 0.202 & 0.973 & 0.551 \\
Body mass index (kg/m $\left.{ }^{2}\right)$ & 0.137 & 0.874 & 0.147 & 0.446 & 0.354 & 0.571 & 0.709 & 0.573 \\
Percentages of body fat (4 SS) & 0.212 & 0.193 & $<0.05(+)$ & 0.750 & 0.101 & 0.650 & 0.546 & 0.230 \\
Percentages of body fat (BIA) & 0.443 & 0.248 & $<0.05(+)$ & 0.180 & 0.134 & 0.592 & 0.925 & 0.178 \\
Triceps skinfold thickness & 0.249 & 0.526 & $<0.05(+)$ & 0.716 & 0.089 & 0.761 & 0.883 & 0.621 \\
Biceps skinfold thickness & $<0.05(+)$ & 0.196 & $<0.01(+)$ & 0.741 & 0.063 & 0.618 & 0.698 & 0.726 \\
Subscapular skinfold thickness & 0.142 & 0.130 & $<0.05(+)$ & 0.301 & 0.136 & 0.434 & 0.812 & 0.348 \\
Suprailiac skinfold thickness & $<0.05(+)$ & 0.233 & $<0.01(+)$ & 0.917 & 0.143 & 0.799 & 0.652 & 0.427 \\
\hline
\end{tabular}

Note: The results are Spearman's correlations ( $p$-value); (+) Significant positive correlation; (-) Significant negative correlation. FC: Functional Capacity; RP: Role Physical; BP: Bodily Pain; GH: General Health; V: Vitality; SF: Social Functioning; RE: Role Emotional; MH: Mental Health; BIA: Bioimpedance Electrical Analysis. Y: Years; 4 SS: Sum 4 folds; M: Months.

per day $(p<0.01)$ and positively correlated with the percentage of body fat given by adding the four skinfold thicknesses $(p<0.01)$ and by BIA $(p<0.05)$. Likewise, the skinfold thicknesses triceps skinfold thickness $(p<0.05)$, biceps skinfold thickness $(p<0.01)$, suprailiac skinfold thickness $(p<0.01)$, and subscapular skinfold thickness $(p<0.05)$ were also positively correlated with the bodily pain domain. The role emotional domain was inversely correlated with time since surgery in years $(p<0.05)$. The mental health domain was positively correlated with age $(p<0.01)$. However, the mental health domain correlated inversely with time since surgery in years and ethanol intake per day in grams $(p<0.05)$.

\section{DISCUSSION}

The mean age, monthly income, per capita monthly income, education level, and number of household members of the two groups were similar. Therefore, the low quality of life of patients with alcoholic chronic pancreatitis can be attributed to the disease and their general situation because many of the patients' social, economic, and educational aspects were similar to those of controls.

The patients had mean disease duration of eight years, defined as the time since diagnosis, not necessarily the time since disease onset. The patients' mean age was $52.98( \pm 9.40)$ years; subtracting mean disease duration from mean age confirms data published by Lowenfels et al. ${ }^{21}$, who found that the mean age of their patients at diagnosis of chronic pancreatitis was 44.6 years. Yet Mullhaupt et al. ${ }^{22}$ found a mean age at alcoholic chronic pancreatitis onset of 36 years in a sample of 265 patients.

A little over half the study patients were diabetic with mean diabetes duration of 4.27 $( \pm 5.99)$ years. These findings disagree with Quilliot et al. ${ }^{23}$, who found that most patients were diabetics with longer disease duration. Probably these different percentages reflect the different outpatient care durations. Diabetic patients had significantly more time since chronic pancreatitis diagnosis than nondiabetic patients.

Most study patients had a history of smoking, corroborating Yadav et al. ${ }^{24}$. About 20\% 
of the study patients had active alcoholism despite constant outpatient care professionals advising against it. In the West the most common cause of chronic pancreatitis is alcohol intake, affecting 70 to $80 \%$ of the patients ${ }^{25,26}$.

All quality of life domains of the patients with alcoholic chronic pancreatitis had significantly lower means than those of controls, indicating considerable impact. Studies have shown that quality of life can be affected by pain and nutritional, metabolic, and gastrointestinal factors, especially in patients with advanced disease ${ }^{11,27}$.

Of the eight Short Form-36 domains, only functional capacity differed between diabetic and non-diabetic patients, indicating that diabetic patients with chronic pancreatitis have even lower quality of life, impairing their ability to carry out activities of daily living, lift objects, or practice sports. However, this difference may stem from disease duration since diabetic patients have longer chronic pancreatitis duration $(p=0.047)$.

How patients perceive their current health in comparison with their health a year ago is important. Chronic pancreatitis patients' health perception was divided mainly between "a bit better" and "almost the same", unlike the control group, where the answer "almost the same" prevailed. Similar results were reported by Pezzilli et al. ${ }^{10}$ with chronic pancreatitis patients: $10.5 \%$ of the patients thought their health was "a bit better"; $52.0 \%$ thought "it was the same"; $21.1 \%$ thought "it was a bit worse"; and $7.6 \%$ thought "it was much worse than a year ago" (p.186). The study results may indicate that symptom relief (especially pain and diarrhea) promoted by multidisciplinary and pharmacological treatment improved perceived health in at least some patients.

The correlations between the quality of life domains and clinical and nutritional factors were significant. Smoking duration hurt functional capacity as worse quality of life was related to longer smoking duration. This is probably due to the fact that smoking is dose dependent and an alcohol-independent risk factor for chronic pancreatitis ${ }^{24}$. Triceps and suprailiac skinfold thicknesses were positively associated with the functional capacity domain because quality of life increased with skinfold thicknesses, indicating that appropriate nutritional status improves quality of life.

The domains role physical, general health, vitality, and social functioning did not correlate with any of the study variables.

The amount of ethanol a day in grams had a negative impact on the domains bodily pain and mental health, indicating that as alcohol intake increased, these quality of life domains worsened. This is probably related to the fact that alcoholic pancreatitis is directly related to the amount of alcohol consumed ${ }^{28}$. Lankish et al. ${ }^{29}$ found that continuous alcohol intake accelerates the disease and is associated with diabetes and greater pain, steatorrhea, morbidity, and mortality.

The percentage of body fat given by the sum of the skinfold thicknesses or BIA correlated positively with the domain bodily pain. Thus, as percentage of body fat improves, bodily pain decreases.

Time since surgery in years had a negative impact on the domains role emotional and mental health, indicating that as time since surgery increases, quality of life in these two domains decreases. It is possible that patients with higher time since surgery had been ill longer, probably experiencing more severe and symptomatic forms of the disease that required surgery because of abdominal pain. The intensity and severity of the pain felt by patients with chronic pancreatitis vary, sometimes leading to unemployment due to frequent hospitalizations, excessive use of medications, and multiple surgeries ${ }^{30}$. Pain treatment in chronic pancreatitis is the main therapeutic conduct to improve quality of life ${ }^{10}$.

The patients' age was important for the mental health domain, indicating that mental health increased with age. Quality of life in younger patients is more compromised than in 
older patients mainly because of recurrent bouts of abdominal pain ${ }^{10,11}$.

Pezzilli et al. ${ }^{10}$ and Wehler et al. ${ }^{11}$ reported that low BMI was associated with worse quality of life. In the present study, BMI did not correlate with any of the eight quality of life domains, maybe because most study patients had appropriate BMI. On the other hand, if only one nutritional assessment tool is used, BMI alone may not be enough to detect malnutrition in this population. This hypothesis is supported by the fact that all other nutritional status indicators (skinfold thicknesses and body composition given by percentage of fat) were positively related to quality of life. Therefore, it is admissible that improvements in nutritional status increase quality of life, and the association of different nutritional assessment methods is essential for accurate determination of these patients' nutritional status.

Finally, considering the study conditions, we can conclude that the eight quality of life domains of the SF-36 are significantly lower in patients with alcoholic chronic pancreatitis than in controls. However, only the domain functional capacity differed between diabetic and nondiabetic patients. Smoking duration, alcohol intake in grams, and time since surgery were negatively correlated with the quality of life of patients with alcoholic chronic pancreatitis. Nonetheless, higher age, skinfold thicknesses, and percentage of body fat were positively correlated with quality of life.

\section{CONTRIBUTORS}

All authors participated in all phases of the research article.

\section{REFERE N CES}

1. Dimagno MJ, Dimagno EP. Chronic pancreatitis. Curr Opin Gastroenterol. 2006; 28(5):523-31. http:// dx.doi.org/10.1097/MOG.0b013e328349e333

2. Meier RF, Begliner C. Nutrition in pancreatic diseases. Best Pract Res Clin Gastroenterol. 2006;
20(3):507-29. http://dx.doi.org/10.1016/j.bpg. 2006.01.004

3. Etemad B, Whitcomb DC. Chronic pancreatitis: Diagnosis, classification, and new genetic developments. Gastroenterology. 2001; 120:682-707. http://dx.doi.org/10.1053/gast.2001.22586

4. Santos RR, Guedes JC, Mello AL, Santana GO, Lyra LG. Consumo protéico e de etanol entre pacientes com pancreatite crônica em Salvador, Bahia: estudo descritivo de 21 casos. Gastroenterol Endosc Dig. 2003; 22(4):123-8.

5. Pimentel FHB, Gómez CIA, Vieira A, Rolim E. Aspectos etiológicos da pancreatite crônica no ambulatório de gastroenterologia da Santa Casa de Misericórdia de São Paulo. Gastroenterol Endosc Dig. 2003; 22(5):193-7.

6. Ware JE, Sherbourne CD. The MOS: 36 item Short Form Health Survey (SF-36) conceptual framework and item selection. Med Care. 1992; 30:473-83.

7. Viacava F. Informações em saúde: a importância dos inquéritos populacionais. Ciênc Saúde Colet. 2002; 7(4):607-21. http://dx.doi.org/10.1590/S14 13-81232002000400002

8. Ciconelli RM, Ferraz MB, Santos W, Meinão I, Quaresma MR. Tradução para a língua portuguesa e validação do questionário genérico de avaliação de qualidade de vida SF-36 (Brasil SF-36). Rev Bras Reumatol. 1999; 39(3):143-50.

9. Ciconelli RM. Tradução para o português e validação do questionário genérico de avaliação de qualidade de vida "medical outcomes study 36-item short form health survey (SF-36)" [tese]. São Paulo: Unifesp; 1997.

10. Pezzilli AM, Morselli L, Ceciliato R, Frulloni L, Cavestro GM, Comparato G, et al. Quality of life in patients with chronic pancreatitis. Dig Liver Dis. 2005; 37(3):181-9. http://dx.doi.org/10.1016/ j.dld.2004.10.007

11. Wehler $M$, Nichterlein $R$, Fischer B, Farnbacher $M$, Reulbach U, Hahn EG, et al. Factors associated with health-related quality of life in chronic pancreatitis. Am J Gastroenterol. 2004; 99(1):138-46. http://dx. doi.org/10.1111/j.1572-0241.2004.04005

12. Andren-Sandberg A, Hoem D, Gislason H. Pain management in chronic pancreatitis. Eur J Gastroenterol Hepatol. 2002; 14(20):957-70. http:// dx.doi.org/10.3748/wjg.14.3137

13. Forsmark CE. Chronic pancreatitis and quality of life. Dig Liver Dis. 2006; 38(2):116-8. http//:dx.doi. org/10.1016/j.dld.2005.10.007

14. Wehler M, Reulbach $U$, Nichterlein R, Lange K, Fischer B, Farnbacher $\mathrm{M}$, et al. Health-related quality of life in chronic pancreatitis: A psychometric assessment. Scand J Gastroenterol. 2003; 
38(10):1083-9. http://dx.doi.org/10.1080/003655 20310005956

15. Universidade Federal de São Paulo. Departamento de Psicobiologia. Porcentagem de etanol nas principais bebidas alcoólicas. São Paulo: Unifesp; 2012 [2012 set 16]. Disponível em http://www. unifesp.br/dpsicobio/drogas/alcool.htm

16. World Health Organization. Obesity: Preventing and managing the global epidemic. Report of a WHO consultation on obesity. Geneva: WHO; 1998.

17. Organización Panamericana de la Salud. Informe preliminar da $36^{a}$ Reunión del Comité Asesor de Investigaciones em Salud - Encuesta Multicéntrica - Salud Bienestar y Envejecimento (SABE) em América Latina y el Caribe. Washington (DC): OPAS; 2002 [acceso 2012 set 15]. Disponible en: http:// www.opas.org/program/sabe

18. Heyward VH, Stolarczyk LM. Avaliação da composição corporal aplicada. São Paulo: Manole; 2000.

19. Durnin JVG, Womersley P. Body fat assessed from total body density and its estimation from skinfold tickness: Measurement in 481 men and women aged from 16 to 72 years. Br J Nutr. 1974; 32(1):77-9.

20. Lohman TG. Advances in body composition assessment: Current issues in exercise science [monograph]. Champaign (II): Human Kinetics Publishers; 1992.

21. Lowenfels AB, Maisonneuve $P$, Cavallini G, Ammann RW, Lankish PG, Andersen JR, et al. Pancreatitis and the risk of pancreatic cancer. International Pancreatitis Study Group. N Engl J Med. 1993; 328(20):1433-7. http://dx.doi.org/10.1056/NEJM 199305203282001

22. Mullhaupt B, Truninger K, Ammann R. Impact of etiology on the painful early stage of chronic pancreatitis: A long-term prospective study. Gastroenterol. 2005; 43(12):1293-301. http://dx.doi. org/10.1055/s-2005-858733
23. Quilliot D, Forbes A, Dubois F, Gueant JL, Ziegler O. Carotenoid deficiency in chronic pancreatitis: The effect of an increase in tomato consumption. Euro J Clin Nutr. 2011; 65(2):262-8. http://dx.doi. org/10.1038/ejcn.2010.232

24. Yadav D, Hawes RH, Brand RE, Anderson MA, Money ME, Banks PA, et al. Alcohol consumption, cigarette smoking, and the risk of recurrent acute and chronic pancreatitis. Arch Intern Med. 2009; 169(11):1035-45. http://dx.doi.org/10.1001/ archinternmed.2009.125

25. Steer ML, Waxman I, Freedman S. Chronic pancreatitis. N Engl J Med. 1995; 332(22):1482-90. http://dx.doi.org/10.1056/NEJM19950601332 2206

26. French JJ, Charnley RM. Chronic pancreatitis. Hepatobiliary Surgery II. 2010; 28(5):212-7.

27. Ammann RW, Akovbiantz A, Largiader F, Schueler $G$. Course and outcome of chronic pancreatitis. Longitudinal study of a mixed medical-surgical series of 245 patients. Gastroenterology. 1984; 86(5 Pt. 1):820-8

28. Bourliere $M$, Barthet $M$, Berthezene $P$, Durbec JP, Sarles $\mathrm{H}$. Is tobacco a risk factor for chronic pancreatitis and alcoholic cirrhosis? Gut. 1991; 32(11):1392-5.

29. Lankish MR, Imoto M, Layer P, Dimagno EP. The effect of small amounts of alcohol on the clinical course of chronic pancreatitis. Mayo Clin Proc. 2001; 76:242-51.

30. Vardanyan M, Rilo HL. Pathogenesis of chronic pancreatitis induced pain. Discov Med. 2010; 9(47):304-10.
Received: March 23, 2015

Final version: August 20, 2015

Approved: September 25, 2015 
